\title{
Purification and partial characterization of the membrane-bound haem- containing proteins from Acinetobacter calcoaceticus LMD 79.41
}

\author{
Paul Dokter, ${ }^{1}$ John E. van Wielink, ${ }^{1}$ Arie Geerlof, ${ }^{1}$ L. Fred Oltmann, ${ }^{2}$ \\ AdriaAn H. Stouthamer ${ }^{2}$ and Johannis A. Duine ${ }^{1 *}$ \\ ${ }^{1}$ Delft University of Technology, Department of Microbiology and Enzymology, Julianalaan 67, 2628 BC Delft, \\ The Netherlands \\ ${ }^{2}$ Department of Microbiology, Biological Laboratory, Vrije Universiteit, De Boelelaan 1087, 1081 HV Amsterdam, \\ The Netherlands
}

(Received 18 April 1990; revised 3 July 1990; accepted 6 August 1990)

\begin{abstract}
Cytoplasmic membranes of Acinetobacter calcoaceticus cells, cultured under acetate-limiting conditions, contain cytochrome $b_{554}$ and a cytochrome $o$-containing oxidase. Both have been purified to homogeneity and characterized. Cytochrome $b_{554}$ is a monomeric protein (molecular mass $70 \mathrm{kDa}$ ) with a midpoint potential of $+100 \mathrm{mV}$ (in the membrane it has most probably a value of $+50 \mathrm{mV}$ ). The cytochrome $o$-containing oxidase seems to be an $\alpha \beta \gamma \delta$ protein since the molecular mass of the native protein was estimated to be $150 \mathrm{kDa}$ and the molecular masses of the subunits, determined by SDS-polyacrylamide-gel electrophoresis, are 55, 41, 33 and $17 \mathrm{kDa}$. Redox spectroscopy of the purified complex shows the presence of a cytochrome $b_{555 / 563}$ having a midpoint potential of approximately $+160 \mathrm{mV}$ (both in purified form and in the membrane). CO difference spectroscopy shows the presence of a second $b$-type cytochrome, viz. cytochrome $o$. Cytoplasmic membranes of $A$. calcoaceticus cells grown under oxygen-limiting conditions also show the presence of the cytochrome $b_{554}$ and the cytochrome $o$-containing oxidase. In addition a protein has been solubilized with the spectral characteristics of a cytochrome $d$-containing oxidase. The cytochrome $o$ - and $d$-containing oxidases appear to be similar to those reported for Escherichia coli and Proteus mirabilis. On the other hand, cytochrome $b_{554}$ has no counterpart in these organisms since the cytochrome $b_{556}$ described for $E$. coli is quite dissimilar.
\end{abstract}

\section{Introduction}

The components of the cytoplasmic-membrane-bound electron-transport chain of Acinetobacter calcoaceticus include flavin, ubiquinone-9, $b$-type cytochromes (including cytochrome $o$ ) and cytochrome $d$ (Asperger $e t$ al. 1978,1981 ; Ensley \& Finnerty, 1980). Cytochrome $o$ and cytochrome $d$ are potentially capable of functioning as terminal oxidases. Cytochrome $o$ is present after growth in the presence of high oxygen concentrations, whereas both cytochrome $o$ and cytochrome $d$ are present after oxygen-limited growth (Ensley \& Finnerty, 1980). In addition it has been shown that the composition of the electron-transport chain does not affect the efficiency of

Abbreviations: $A_{\mathrm{m}}^{*}$, absorbance maximum at full reduction; $\lambda_{\mathrm{m}}$, wavelength $(\mathrm{nm})$ at the absorbance maximum; $\omega_{\lambda}$, band width $(\mathrm{nm})$ at $A=0.5 A_{\mathrm{m}}$; cytochrome $b_{554}$, cytochrome $b$ with an $\alpha$-band maximum in the reduced form at $77 \mathrm{~K}$ at $554 \mathrm{~nm}$ (cytochromes $b_{558}$ and $b_{556}$ have been defined in the same way); cytochrome $b_{555 / 563}$, cytochrome $b$ with a split $\alpha$-band in the reduced form at $77 \mathrm{~K}$ (maxima at 555 and $563 \mathrm{~nm}$ ); $E_{0}^{\prime}$, midpoint potential at $\mathrm{pH} 7.0 ; \mathrm{GDH}$, glucose dehydrogenase; TMBZ, tetramethylbenzidine. the electron-transport-coupled synthesis of ATP (Ensley et al., 1981).

By virtue of the reaction glucose $\rightarrow$ gluconolactone $+2 \mathrm{H}^{+}+2 \mathrm{e}^{-}$, catalysed by pyrroloquinoline quinone (PQQ)-containing glucose dehydrogenase (GDH), reducing equivalents can be donated to the electrontransport chain. Recently, evidence has been presented for the existence of two different GDHs in A. calcoaceticus (Cleton-Jansen et al., 1988; Matsushita et al., 1988): a membrane-bound GDH ( $83 \mathrm{kDa}$, one subunit), presumably related to the GDHs in Escherichia coli and Pseudomonas sp. (Ameyama et al., 1986; Matsushita et al. 1986), and a soluble GDH (approx. $100 \mathrm{kDa}$, two subunits) located in the periplasm and closely associated with the soluble cytochrome $b$-562 (Dokter et al., 1985, 1986, 1988; Geiger \& Görisch, 1986).

It has been suggested by Ameyama and co-workers that the membrane-bound GDH donates reducing equivalents directly to ubiquinone (Matsushita et al., 1987; Ameyama et al., 1986). Also Beardmore-Gray \& Anthony (1986) suggested a direct electron transport 
from the membrane-bound GDH to ubiquinone. Moreover, they argued that the 'glucose oxidase' system of $A$. calcoaceticus is kinetically distinct from the 'NADH oxidase' system, although both the GDH and the NADH dehydrogenase were assumed to donate electrons via ubiquinone-9, the $b$-type cytochromes and the cytochrome $o$-type oxidase to oxygen. In contrast to this direct electron transfer to ubiquinone, for the soluble GDH it has been suggested that the soluble cytochrome $b$-562 functions between the GDH and ubiquinone (Hauge, 1960, 1961; Dokter et al., 1988).

To elucidate the bioenergetic significance of the GDHs in A. calcoaceticus, insight into the identity of the components and the structure of its respiratory chain is necessary. The present paper describes the haemcontaining proteins of the cytoplasmic membrane, investigated by means of coupled spectrum deconvolution and potentiometric analysis. In addition, two haemcontaining proteins, viz. the cytochrome $o$-containing oxidase and the cytochrome $b_{554}$, were purified and characterized. Their resemblances to those of $E$. coli and Proteus mirabilis are discussed.

\section{Methods}

Cell growth. Acinetobacter calcoaceticus LMD 79.41 was grown either in an acetate-limited continuous culture (cells provided by Dr B. J. van Schie: Van Schie et al., 1984), or in (oxygen-limited) fed-batch cultures with acetate as a carbon and energy source (Dokter et al., 1985). The cells were harvested and subsequently stored at $-20^{\circ} \mathrm{C}$.

Chemicals. All chemicals were obtained from commercial sources and were of reagent grade.

Membrane isolation. Cytoplasmic membranes were prepared by the method of Widdowson \& Anthony (1975).

Solubilization of membrane-bound haem-containing proteins. To solubilize cytochrome-containing complexes from the cytoplasmic membranes, the membranes ( $5 \mathrm{mg}$ protein $\mathrm{ml}^{-1}$ ) were incubated overnight at $4{ }^{\circ} \mathrm{C}$ in $10 \mathrm{~mm}$-Tris $/ \mathrm{HCl}$ buffer, $\mathrm{pH} 8.0$, containing $10 \mathrm{~mm}-\mathrm{MgCl}_{2}$ and $5 \%(\mathrm{w} / \mathrm{v})$ Triton $\mathrm{X}-100(\mathrm{Kita}$ et al., 1986). The suspension was centrifuged for $2 \mathrm{~h}$ at $100000 \mathrm{~g}$. The supernatant, referred to as the 'Triton X-100 extract', contained the solubilized proteins.

Purification of the solubilized haem-containing proteins. The Triton X100 extract $\left(215 \mathrm{ml}, 3.2 \mathrm{mg}\right.$ protein $\left.\mathrm{ml}^{-1}\right)$ was applied to a DEAESepharose CL-6B Fast Flow column $(2.2 \mathrm{~cm} \times 24 \mathrm{~cm})$ equilibrated with TE buffer ( $10 \mathrm{~mm}$-Tris/ $\mathrm{HCl}$ buffer, $\mathrm{pH} 8 \cdot 0$, containing $1 \mathrm{~mm}$ EDTA and $1 \%$, w/v, Triton X-100). The column was washed with TE buffer, and the proteins were then eluted with a linear gradient of 0 $0 \cdot 2 \mathrm{M}-\mathrm{NaCl}$ in TE buffer. Fractions $(8 \mathrm{ml})$ with a significant difference in absorbance at 408 and $440 \mathrm{~nm}$ were pooled, concentrated by pressure filtration (Millipore, membrane type PTGC 047), and stored at $-70^{\circ} \mathrm{C}$. In the case of the cytochrome $o$-containing oxidase, the concentrate $\left(10 \mathrm{ml}, 7.3 \mathrm{mg}\right.$ protein $\left.\mathrm{ml}^{-1}\right)$ was diluted with TE buffer to lower the $\mathrm{NaCl}$ concentration (end volume about $40 \mathrm{ml}$ ). The diluted sample was applied to a DEAE-Sepharose column $(1.1 \mathrm{~cm} \times 8.4 \mathrm{~cm})$ and chromatography was performed as described above.
Molecular mass determinations. Molecular mass determinations of native cytochrome complexes were made on polyacrylamide gradient gels (Pharmacia, PAA 4/30), using proteins of high- and low-molecularmass electrophoresis calibration kits as references [method described in the Pharmacia manual Laboratory Techniques (1986)]. Electrophoresis under denaturing conditions (in the presence of $1 \%, w / v$, SDS) and cytochrome staining (with tetramethylbenzidine: TMBZ) were carried out according to Thomas et al. (1976). Protein staining was performed with Coomassie Brilliant Blue R250.

Protein determinations. Protein concentrations were determined by the Lowry method, with bovine serum albumin as a standard. To remove the Triton $\mathrm{X}-100$, which would interfere in the protein determinations, a column of Bio-beads (Bio-Rad) was used (Holloway, 1973).

Cytochrome analysis. During the purification procedure, cytochrome $b$ concentrations were estimated from reduced-minus-oxidized diference spectra, by using a molar difference absorption coefficient $\left(\varepsilon_{560-}\right.$ 575) of $22 \mathrm{mM}^{-1} \mathrm{~cm}^{-1}$ (Chance, 1957). Absorption spectra of cytoplasmic membranes were recorded with a Beckman UV 5260 spectrophotometer, placing the cuvette holder just in front of the photomultiplier; those of optically clear cytochrome preparations were recorded with a Hewlett-Packard model HP 8450 A spectrophotometer.

Pyridine haemochrome spectra were measured in aqueous alkaline pyridine solutions and the haem content was determined by the method of Fuhrhop \& Smith (1975).

For detailed characterization of the cytochromes, spectra were recorded with a DW-2a spectrophotometer (American Instrument Co.) equipped with a low-temperature accessory (J4-9603, American Instrument Co.). To improve the signal-to-noise ratio of $77 \mathrm{~K}$ spectra, the averages of nine sequential scans were used (Van Wielink et al., 1982). To determine CO-spectra, $\mathrm{CO}\left(\mathrm{O}_{2} \leq 3\right.$ p.p.m.) was flushed over the solution. Reduction of the cytochromes was accomplished by dithionite. After flushing for $90 \mathrm{~min}$ at room temperature, an absorption spectrum was recorded and a sample was taken for a $77 \mathrm{~K}$ spectrum. To prevent light-induced dissociation of the $\mathrm{CO}$-liganded complexes, freezing and storage of these samples took place in the dark.

Flash-photolysis. Light-induced dissociation of the CO-liganded complexes in the frozen samples was accomplished by four flashes of a Rollei E22C flash lamp. After each flash the cuvette was submerged in liquid nitrogen. Since the crystal structure did not change, the spectra recorded before and after the treatment could be compared without corrections.

Potentiometric titrations. The cytoplasmic membranes and the solubilized cytochrome-containing complexes were titrated in $0.1 \mathrm{M}$ HEPES, pH $7 \cdot 0$ at $25^{\circ} \mathrm{C}$, using the mediator cocktail and equipment as described by Van Wielink et al. (1982). Reductive titrations were performed by stepwise addition of an anaerobic solution of NADH or, to achieve low redox potentials, sodium dithionite. In oxidative titrations, the contents of the titration vessel were first reduced with sodium dithionite, then oxidized by stepwise addition of an anaerobic solution of potassium ferricyanide.

Oxidase activity. The oxidase activity was measured polarographically at $30^{\circ} \mathrm{C}$ in air-saturated $0.1 \mathrm{~m}$-potassium phosphate buffer, $\mathrm{pH} 7.0$, containing $0.05 \%(\mathrm{w} / \mathrm{v})$ Triton X-100 with duroquinol as electron donor (Matsushita et al., 1984). Initial oxygen consumption rates were calculated from the slopes induced by addition of duroquinol $(0.017-$ $0.417 \mathrm{~mm}$ ). Duroquinol was prepared from duroquinone by a method described by White et al. (1978). 


\section{Results}

Spectral characterization of the b-type cytochromes in the membrane

Cytoplasmic membranes from acetate-limited chemostat-grown cells and from oxygen-limited fed-batchgrown cells contained at least three $b$-type cytochromes, as revealed from analysis of series of $77 \mathrm{~K}$ spectra of membrane samples poised at different redox potentials (Fig. 1, Table 1). Cytochrome $b_{554-555}\left(E_{0}^{\prime}=+50 \mathrm{mV}\right)$ and cytochrome $b_{555 / 563}(+160 \mathrm{mV})$, the latter with a split $\alpha$-band [or cytochrome $b_{555}(+165 \mathrm{mV})$ and cytochrome $b_{563}(+160 \mathrm{mV})$ ], contributed equally to the absorption band between 540 and $580 \mathrm{~nm}$ in both cytoplasmic membrane preparations. In addition to these cytochromes a low contribution of a cytochrome $b_{558}(+170 \mathrm{mV})$ was necessary to fit the data of membranes from oxygen-limited cells. (In Table 1 the components which may be identical are depicted side by side on one line.)

\section{Solubilization and fractionation of the haem-containing proteins}

The solubilization procedure applied to membranes of acetate-limited cells resulted in a preparation giving two chromatographically different haem-containing proteins on the DEAE-Sepharose column (fractions I and II; Fig. 2). Fraction I appeared to be a cytochrome $o$-type oxidase in view of its spectral characteristics and its duroquinol oxidase activity (see below). Fraction II showed no oxidase activity and according to its absorption maximum at $77 \mathrm{~K}$, it was designated as cytochrome $b_{554}$. Both fractions were also obtained from membranes prepared from oxygen-limited fed-batch-grown cells, although a third haem-containing fraction (eluting before fraction I) was observed in this case. This appeared to be a cytochrome $d$-type oxidase in view of its spectral

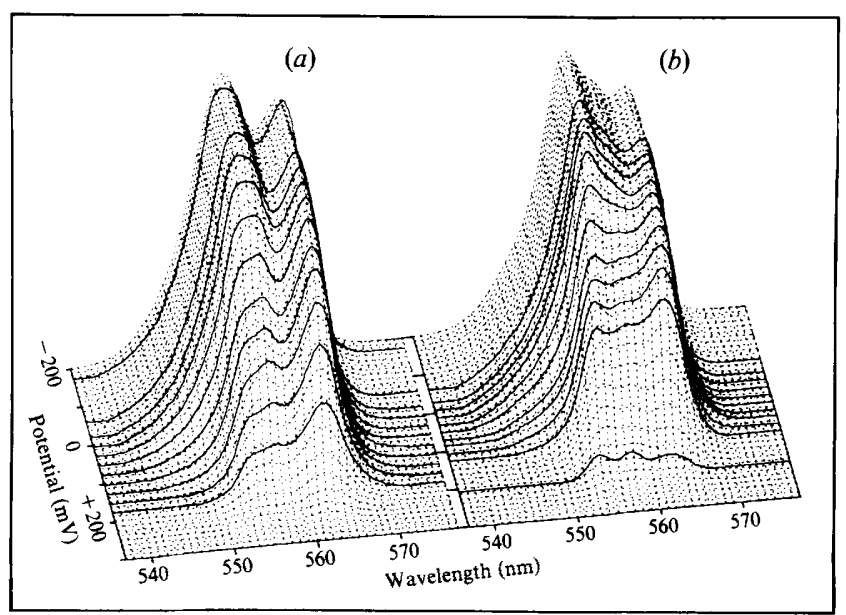

Fig. $1.77 \mathrm{~K}$ spectra of cytoplasmic membranes from $A$. calcoaceticus poised at different redox potentials. Cytoplasmic membranes were isolated from $(a)$ cells of an acetate-limited chemostat culture and $(b)$ cells of an $\mathrm{O}_{2}$-limited fed-batch culture. The solid lines represent the recorded $77 \mathrm{~K}$ spectra. The reticular broken lines represent the fittings based on the assumption of three components $(a)$ and four components (b). For parameter values see Table 1 .

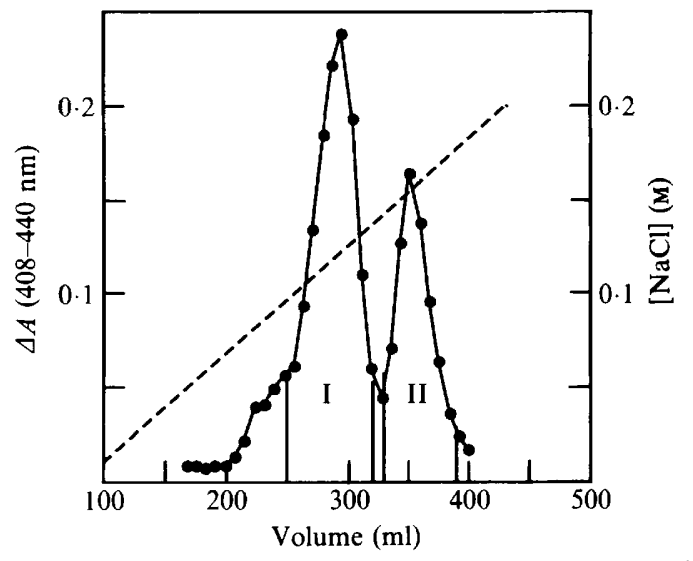

Fig. 2. DEAE-Sepharose column chromatography of the solubilized haem-containing proteins from cytoplasmic membranes isolated from cells of an acetate-limited chemostat culture. The pooled fractions are indicated by I and II. For further details see Methods.,$- \triangle A(408-$ $440 \mathrm{~nm}) ;---, \mathrm{NaCl}$ concentration.

Table 1. Best-fitting parameters for the potentiometric titrations of the cytochromes b present in cytoplamic membranes of cells grown under acetate or oxygen limitation

$77 \mathrm{~K}$ spectra from cytoplasmic membrane samples, poised at different redox potentials (see Fig. $1 a, b$ ) were simulated by using a combination of the Nernst equation and the Gauss equation. The amount of a component was estimated from the spectral area occupied by that component, indicated as a percentage of the spectral area at full reduction. $A_{\mathrm{m}}^{*}$ is the maximum absorbance at $\lambda_{\mathrm{m}}$ on full reduction, $\lambda_{\mathrm{m}}$ is the wavelength $(\mathrm{nm})$ of the absorption maximum, $\omega_{\lambda}$ is the band width (nm) at halfheight, and $E_{0}^{\prime}$ is the midpoint potential $(\mathrm{mV})$ for the component at $\mathrm{pH} 7 \cdot 0$.

\begin{tabular}{|c|c|c|c|c|c|c|c|c|c|}
\hline \multicolumn{5}{|c|}{ Acetate-limited, chemostat } & \multicolumn{5}{|c|}{ Oxygen-limited, fed-batch } \\
\hline$\%$ & $A_{\mathrm{m}}^{*}$ & $\lambda_{\mathrm{m}}(\mathrm{nm})$ & $\omega_{\lambda}(\mathrm{nm})$ & $E_{0}^{\prime}(\mathrm{mV})$ & $\%$ & $A_{\mathrm{m}}^{*}$ & $\lambda_{\mathrm{m}}(\mathrm{nm})$ & $\omega_{\lambda}(\mathrm{nm})$ & $E_{0}^{\prime}(\mathrm{mV})$ \\
\hline 29 & $0 \cdot 042$ & $562 \cdot 9$ & $5 \cdot 8$ & +168 & $\begin{array}{r}30 \\
8\end{array}$ & $\begin{array}{l}0.038 \\
0.017\end{array}$ & $\begin{array}{l}562 \cdot 6 \\
558 \cdot 2\end{array}$ & $\begin{array}{l}5 \cdot 7 \\
3 \cdot 6\end{array}$ & $\begin{array}{l}+152 \\
+170\end{array}$ \\
\hline 23 & 0.029 & 555.7 & $6 \cdot 3$ & +159 & 16 & 0.026 & $554 \cdot 6$ & $4 \cdot 3$ & +168 \\
\hline 48 & 0.031 & 554.9 & $12 \cdot 5$ & +45 & 46 & 0.027 & $554 \cdot 2$ & $12 \cdot 2$ & +52 \\
\hline
\end{tabular}




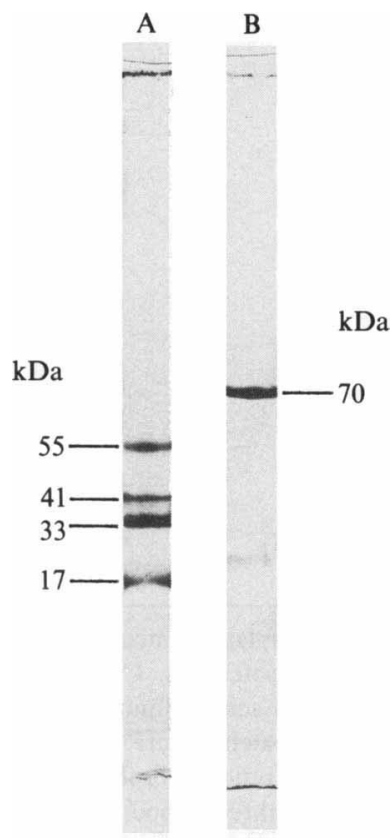

Fig. 3. SDS-polyacrylamide gel electrophoresis of the purified cytochrome $o$-type oxidase (lane A) and the cytochrome $b_{554}$ (lane B), followed by protein staining.

characteristics (in the reduced form absorption bands at 560,595 and $635 \mathrm{~nm}$ ). Due to the instability of the preparation (as observed from the disappearance of the absorption bands), no attempts were made to purify the oxidase.

The purification schemes of the cytochrome $o$-type oxidase and the cytochrome $b_{554}$ are given in Table 2 .

\section{Characterization of the cytochrome o-type oxidase}

The maximum rate of oxygen consumption of the purified cytochrome $o$-type oxidase was $2.5 \mu \mathrm{mol} \mathrm{O}_{2}$ per nmol cytochrome $o$ per minute with duroquinol as electron donor (the apparent $K_{\mathrm{m}}$ for duroquinol was $0 \cdot 1 \mathrm{mM}$ ).

Protein staining after electrophoresis of the cytochrome $o$-type oxidase (after the second DEAE-Sepharose chromatography step) on polyacrylamide gradient gels revealed only one band, of $150 \mathrm{kDa}$ (results not shown), indicating that the preparation was homogeneous. Under denaturing conditions, bands of 55, 41, 33 and $17 \mathrm{kDa}$ were visible (Fig. 3). As revealed by the TMBZ staining procedure, only the $55 \mathrm{kDa}$ band contained haem.

Pyridine haemochrome spectra of the cytochrome $o$ type oxidase clearly indicated the presence of protohaem (in reduced-minus-oxidized difference spectra, maxima at 418,526 and $557 \mathrm{~nm}$ and a minimum at $541 \mathrm{~nm}$ were found). The haem content appeared to be $8.5 \mathrm{nmol}$ haem (mg protein) $)^{-1}$, that is 1.3 haem groups per molecule of cytochrome $o$-type oxidase $(150 \mathrm{kDa})$. This value might indicate either the inaccuracy of the determinations or the possibility that in vivo the $o$-type oxidase contains two haem groups and that haem has apparently been detached from the protein during purification.

Spectra recorded at $25^{\circ} \mathrm{C}$ of the oxidized cytochrome $o$-type oxidase showed a $\gamma$-band at $406 \mathrm{~nm}$, whereas the reduced oxidase preparation showed bands at $426 \mathrm{~nm}(\gamma-$ band), $530 \mathrm{~nm}$ ( $\beta$-band) and $564 \mathrm{~nm}$ with a shoulder at $558 \mathrm{~nm}(\alpha$-bands; see Fig. $4 a$ ). At $77 \mathrm{~K}, \alpha$-bands were found at 554.5 and $564 \mathrm{~nm}$ (Fig. $5 a$ ). In the reducedminus-oxidized spectrum at $25^{\circ} \mathrm{C}$, peaks were found at $428,530,558$ (shoulder) and $564 \mathrm{~nm}$, and a trough at $406 \mathrm{~nm}$ (Fig. $4 b$ ). From these spectra molar absorption coefficients of $16.1\left(\varepsilon_{564-580}\right)$ and $250 \mathrm{~mm}^{-1} \mathrm{~cm}^{-1}\left(\varepsilon_{428-}\right.$ ${ }_{406}$ ) were calculated (assuming the presence of two haem groups per oxidase molecule).

The cytochrome $o$-type oxidase (the cytochrome $o$ part) appeared to bind $\mathrm{CO}$ since the CO-difference spectrum (the oxidase reduced in the presence of carbon

Table 2. Purification of the cytochrome o-type oxidase and the cytochrome $b_{554}$

The proteins were purified from acetate-limited chemostat cells. For further details see Methods.

\begin{tabular}{lcccc}
\hline Preparation & $\begin{array}{c}\text { Cyt. } b \\
(\mathrm{nmol})\end{array}$ & $\begin{array}{c}\text { Yield } \\
(\%)\end{array}$ & $\begin{array}{c}\text { Protein } \\
(\mathrm{mg})\end{array}$ & $\begin{array}{c}\text { Cyt. } b / \text { protein }^{\circ} \\
\text { ratio }\left(\mathrm{nmol} \mathrm{mg} \mathbf{~ m}^{-1}\right)\end{array}$ \\
\hline Crude extract & 1299 & 100 & 4292 & $0 \cdot 3$ \\
Cytoplasmic membranes & 947 & 73 & 1229 & $0 \cdot 8$ \\
Triton X-100 extract & 573 & 44 & 690 & $0 \cdot 8$ \\
Cytochrome $o$-type oxidase* & 256 & 20 & 73 & $3 \cdot 5$ \\
Cytochrome $o$-type oxidase $\dagger$ & 223 & 17 & 45 & $5 \cdot 0(8 \cdot 5 \ddagger)$ \\
Cytochrome $b_{554^{*}}$ & 174 & 13 & 134 & $1 \cdot 3(3 \cdot 7 \ddagger)$ \\
\hline \hline
\end{tabular}

* After the first DEAE-Sepharose chromatography step.

$\dagger$ After the second DEAE-Sepharose chromatography step.

$\ddagger$ Haem content [nmol haem (mg protein) ${ }^{-1}$ ] determined by pyridine haemochrome method of Fuhrhop \& Smith (1975). 


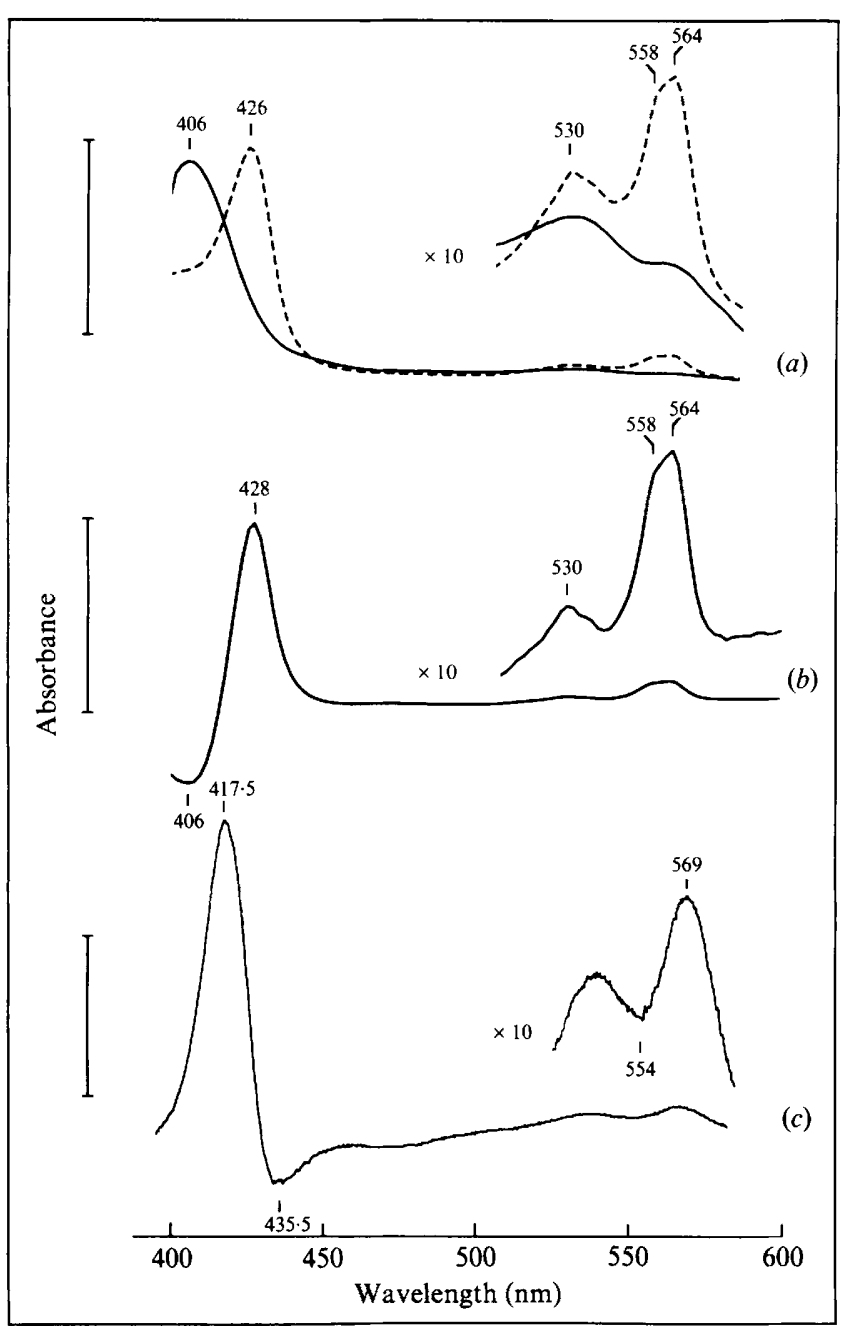

Fig. 4. Absorption spectra of the cytochrome $o$-type oxidase. The purified oxidase preparations contained $0.64 \mathrm{mg}$ protein $\mathrm{ml}^{-1}(a$ and $b$ ) $1.0 \mathrm{mg}$ protein $\mathrm{ml}^{-1}(c)$ in $0.1 \mathrm{M}$-HEPES, $\mathrm{pH} 7.0$, at $25^{\circ} \mathrm{C}$. (a) oxidized form; ---, reduced form (after reduction by dithionite). (b) Reduced minus oxidized. (c) CO-difference spectrum (reduced by dithionite in the presence of $\mathrm{CO}$ minus reduced in the presence of argon). The vertical bars represent a $\Delta A$ of $0 \cdot 5$.

monoxide minus the oxidase reduced in the presence of argon) showed maxima at 417.5 and $569 \mathrm{~nm}$ and troughs at 435.5 and $554 \mathrm{~nm}$ (Fig. $4 c$ ). The molar absorption coefficient $\left(\varepsilon_{417.5-435.5}\right)$, based on two haems per oxidase molecule, was $218 \mathrm{~mm}^{-1} \mathrm{~cm}^{-1}$. At $77 \mathrm{~K}$, peaks were found at 417 and $566.5 \mathrm{~nm}$ and troughs at 438.5 and $553 \mathrm{~nm}$ (Fig. $5 b$ ).

By applying light flashes to the CO-treated, reduced sample, part of the $\mathrm{CO}$ could be dissociated from the complex. Since reassociation at $77 \mathrm{~K}$ is slow, the effect of four light flashes could be visualized by subtraction of a $77 \mathrm{~K}$ spectrum of a reduced sample treated with $\mathrm{CO}$ and flash light from a spectrum of the same sample not treated with flash light. Peaks were detected at $413.5 \mathrm{~nm}$ and $566 \mathrm{~nm}$, and troughs at $431 \mathrm{~nm}$ and $533 \mathrm{~nm}$ (Fig. 5 c).

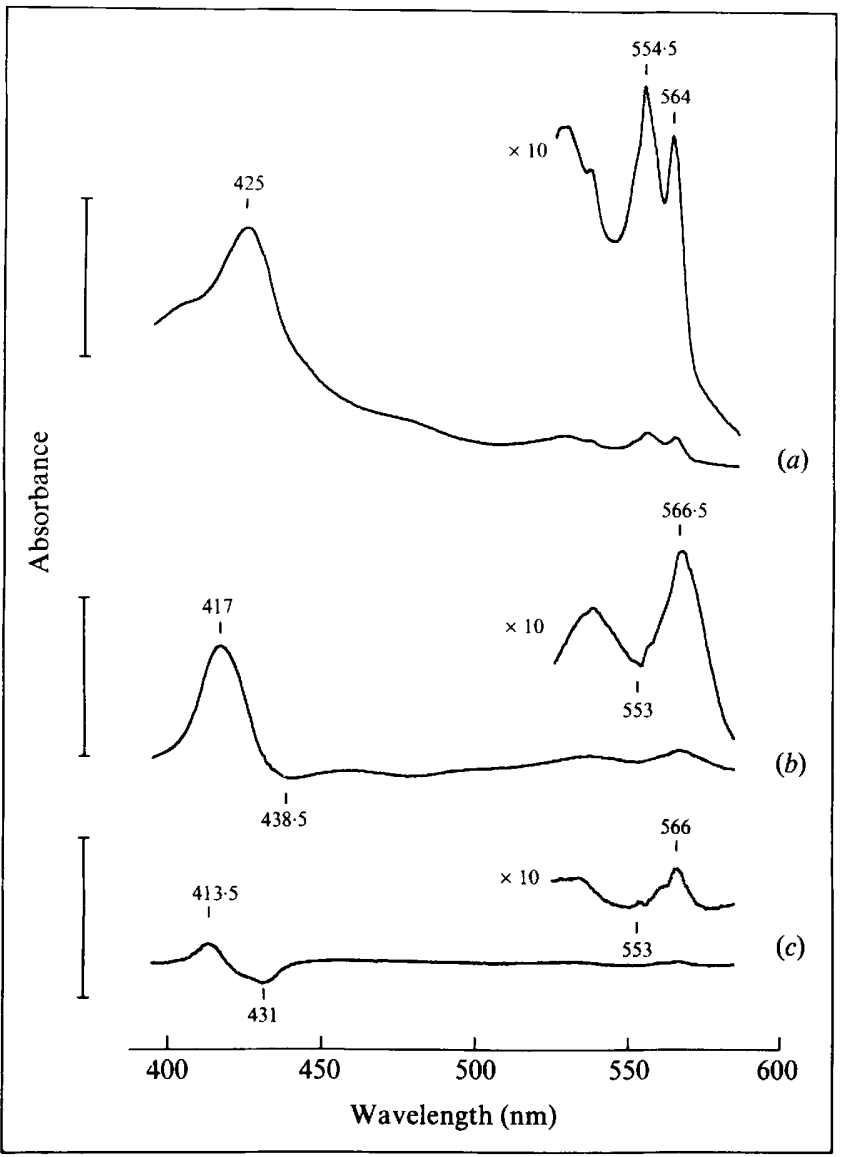

Fig. $5.77 \mathrm{~K}$ spectra of the cytochrome $o$-containing oxidase. The spectra were taken of samples containing $1 \mathrm{mg}$ cytochrome $o$ oxidase $\mathrm{ml}^{-1}$ under the following conditions : reduced by dithionite $(a)$; reduced in the presence of $\mathrm{CO}$ minus reduced in the presence of $\operatorname{Ar}(b)$; reduced in the presence of $\mathrm{CO}$ minus reduced in the presence of $\mathrm{CO}$ and treated with four light flashes $(c)$. The vertical bars represent a $\Delta A$ of 0.5 .

The small troughs in the CO-difference spectra, recorded at $25^{\circ} \mathrm{C}$ (Fig. $4 c$ ), might indicate that the contribution of cytochrome $o$ (red) to the Soret-band as well as to the $\alpha$-band, is very small. In contrast, that of cytochrome $o$ (red)-CO is more pronounced, as apparent from the peaks in Fig. 4(c) and 5(b).

The midpoint potential of the main cytochrome $b$ component (79\%, see Fig. 6), contributing to the $\alpha$-band of the cytochrome $o$-containing oxidase, was $+177 \mathrm{mV}$. The component having a low midpoint potential $(-20 \mathrm{mV})$, occupying $21 \%$ of the spectral area in the $540-580 \mathrm{~nm}$ region might originate from denatured cytochrome(s) $b$.

Characterization of the cytochrome $b_{554}$

The cytochrome $b_{554}$ preparation appeared to be homogeneous, as revealed by polyacrylamide gel electrophoresis after protein staining as well as haem staining. 


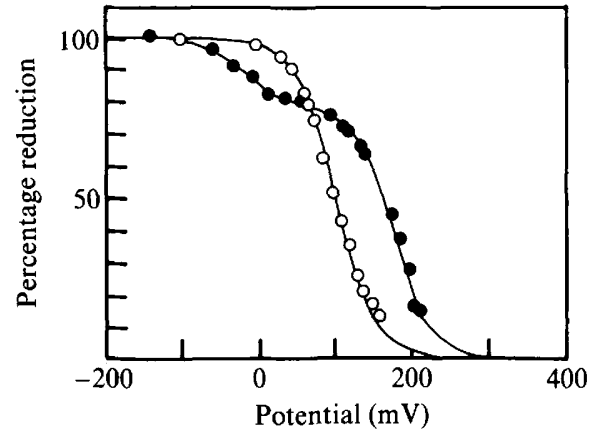

Fig. 6. Potentiometric titration of the purified cytochrome $o$-containing oxidase (O) and the cytochrome $b_{554}(\mathrm{O})$. The percentage reduction of the cytochromes in the preparations (calculated from the peak areas of $\alpha$-bands in the $540-580 \mathrm{~nm}$ region) are plotted vs the redox potential. Protein contents: $1.0 \mathrm{mg} \mathrm{ml}^{-1}$ (the cytochrome $o$-containing oxidase) and $0.66 \mathrm{mg} \mathrm{ml}^{-1}$ (the cytochrome $b_{554}$ ). The lines represent best-fit analyses with two components for the titration of the cytochrome $o$ containing oxidase $(21 \%$ of the area underneath the $\alpha$-band titrates with a midpoint potential of $-20 \mathrm{mV}, 79 \%$ with a midpoint potential of $+177 \mathrm{mV}$ ) and with one component for the titration of the cytochrome $b_{554}(100 \%$ of the area underneath the $\alpha$-band titrates with a midpoint potential of $+100 \mathrm{mV}$ ).

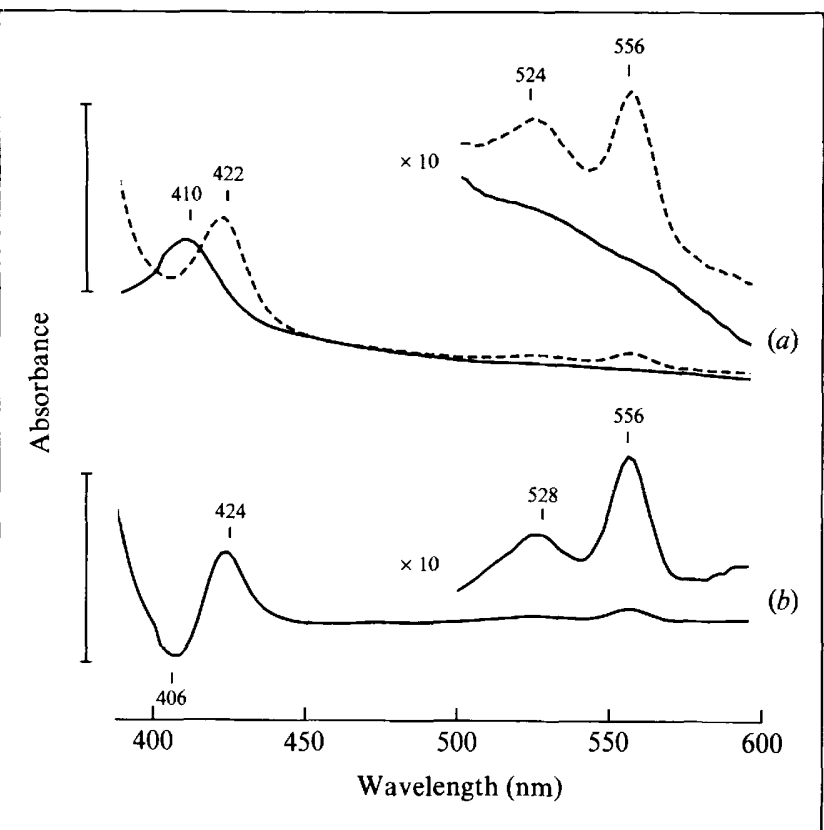

Fig. 7. Spectra of a cytochrome $b_{554}$ preparation at $25^{\circ} \mathrm{C}$. Samples contained $0.66 \mathrm{mg}$ cytochrome $b_{554} \mathrm{ml}^{-1}$. (a) Spectra of the oxidized form (-) and the dithionite-reduced form (-- ). (b) The difference spectrum (reduced minus oxidized). The vertical bars represent a $\triangle A$ of $0 \cdot 5$.

This cytochrome is a monomeric protein since a molecular mass of $70 \mathrm{kDa}$ was found for the native as well as for the denatured form (Fig. 3).

Pyridine haemochrome spectra showed the presence of protohaem : $3.7 \mathrm{nmol}$ haem (mg protein $)^{-1}$ or $0.25 \mathrm{~mol}$
Table 3. Comparison of cytochrome o-containing oxidases

For data of A. calcoaceticus, see this paper. The ranges of data for the $E$. coli oxidase were compiled from Kranz \& Gennis (1983), Matsushita et al. (1983, 1984), Kita et al. (1984a) and Anraku \& Gennis (1987). NM, Not measured.

\begin{tabular}{llc}
\hline \hline & \multicolumn{2}{c}{ Cytochrome $o$-containing oxidase from: } \\
\cline { 2 - 3 } Property & \multicolumn{1}{c}{ A. calcoaceticus } & $E$. coli \\
\hline Mol. mass & & \\
$(\mathrm{kDa}$, native) & 150 & 140 \\
Mol. mass & & \\
$(\mathrm{kDa}$, denatured) & 55 (haem) & $51-66$ (haem) \\
& 41 & $28-36$ \\
& 33 & $18-22$ \\
& 17 & $13-17$ \\
$E_{0}^{\prime}(\mathrm{mV})$ & $b_{555 / 563}:+160$ & $b_{562}:+150$ \\
& \multicolumn{1}{c}{$o_{554}: \mathrm{NM}$} & $o_{555}:+150$ \\
\hline \hline
\end{tabular}

haem (mol protein $)^{-1}(70 \mathrm{kDa})$. The latter value strongly suggests that loss of haem occurred during purification.

Spectra of the oxidized cytochrome $b_{554}$, recorded at $25^{\circ} \mathrm{C}$, showed a $\gamma$-band at $410 \mathrm{~nm}$. The reduced cytochrome showed bands at $422 \mathrm{~nm}(\gamma$-band), $524 \mathrm{~nm}$ ( $\beta$-band) and $556 \mathrm{~nm}(\alpha$-band; see Fig. $7 a$ ). At $77 \mathrm{~K}$, the $\alpha$-band was found at $554 \mathrm{~nm}$ (consequently the cytochrome is designated as cytochrome $b_{554}$ ). In the reduced-minus-oxidized spectrum at $25^{\circ} \mathrm{C}$, maxima were found at 424, 528 and $556 \mathrm{~nm}$, and a trough at $406 \mathrm{~nm}$ (Fig. $7 b$ ). Molar absorption coefficients calculated from the reduced-minus-oxidized spectra are: $\varepsilon_{424-406}=$ $119 \mathrm{~mm}^{-1} \mathrm{~cm}^{-1}$ and $\varepsilon_{556-576}=13.3 \mathrm{~mm}^{-1} \mathrm{~cm}^{-1}$ (assuming the presence of one haem per cytochrome $b_{554}$ ).

Cytochrome $b_{554}$ did not bind $\mathrm{CO}$ (spectra not shown). The midpoint potential of cytochrome $b_{554}$ was $+100 \mathrm{mV}$.

\section{Discussion}

Cytochrome $b_{554}$ and cytochrome $o$-type oxidase are very major components of the cytoplasmic membranes of $A$. calcoaceticus, as can be deduced from the purification schemes (Table 2). After growth under oxygen-limiting conditions cytochrome $d$-type oxidase is also found.

Comparison of the properties of the cytochrome $o$-type oxidase from $A$. calcoaceticus with those of the $E$. coli oxidase (Table 3), reveals similarity (although there are significant differences in the subunit molecular masses). Based on the absorbance changes induced by $\mathrm{CO}$, it is concluded that the reduced cytochrome $o$ of $A$. calcoaceticus only slightly contributed to the absorbance between 540 and $580 \mathrm{~nm}$ [main absorbance assigned to cytochrome $b_{555 / 563}\left(E_{0}^{\prime}\right.$ approx. $\left.\left.+160 \mathrm{mV}\right)\right]$. For the cytochrome $o$-type oxidase of $E$. coli, Hackett \& Bragg (1983) came to the same conclusion. Lorence et al. (1984), 
however, attributed both the 555 and the $562 \mathrm{~nm}$ bands to cytochrome $o$, while Kita et al. $(1984 a, 1986)$ attributed the band at $555 \mathrm{~nm}$ to cytochrome $o$. The band at $562 \mathrm{~nm}$ was assigned to the other cytochrome in the oxidase (see also Anraku \& Gennis, 1987). The midpoint potentials of cytochrome $o$ and cytochrome $b_{562}$ were found to be identical $\left(E_{0}^{\prime}=+150 \mathrm{mV}\right)$.

Under oxygen-limited conditions the synthesis of cytochrome $d$ is induced in $A$. calcoaceticus (Ensley \& Finnerty, 1980). The presence of cytochrome $b_{558}$ $\left(E_{0}^{\prime}=+170 \mathrm{mV}\right)$ in $A$. calcoaceticus LMD 79.41 suggests a similar cytochrome $b_{558^{-}} d$-containing oxidase as reported for E. coli (Miller \& Gennis, 1983; Hata et al., 1985). This view is in agreement with the finding of Kranz \& Gennis (1985), who showed that the cytochrome $d$ complex of Acinetobacter HO1-N is immunologically related to the cytochrome $d$ complex of $E$. coli.

The third haem-containing protein purified from the membranes of $A$. calcoaceticus is cytochrome $b_{554}\left(E_{0}^{\prime}\right.$ approx. $+100 \mathrm{mV})$. The protein consists of one polypeptide chain $(70 \mathrm{kDa})$ with at least one haem group. It may be identical to cytochrome $b_{554-555}$ ( $E_{0}^{\prime}$ approx. $+50 \mathrm{mV}$ ) detected during titrations of the cytoplasmic membranes (see Table 1). Cytochrome $b_{554}$ is different from the cytochrome $b_{556}$ that Kita et al. (1978) solubilized from cytoplasmic membranes of $E$. coli, since the latter is an oligomer composed of polypeptides of $17.5 \mathrm{kDa}$, with a much lower midpoint potential ( $-45 \mathrm{mV}$ according to Kita et al., 1978; $+35 \mathrm{mV}$ according to Lorence et al., 1984). Initially it was suggested that this cytochrome is required for electron transfer to the cytochrome $o$-type oxidase (Haddock \& Jones, 1977; Kita \& Anraku, 1981) and, possibly, the cytochrome $d$-type oxidase (Kita et al., 1984b). For aerobically grown $P$. mirabilis, it has been suggested that a cytochrome $b_{557}\left(E_{0}^{\prime}=+50 \mathrm{mV}\right)$ may function (together with cytochrome $b_{563 / 556}, E_{0}^{\prime}=+140 \mathrm{mV}$ ) in a Q- or $b$-cycle (Van Wielink et al., 1983). On the other hand, the cytochrome $d$-containing oxidase of $E$. coli (Koland et al., $1984)$ and the cytochrome $o$-containing oxidase of both E. coli (Carter \& Gennis, 1985) and A. calcoaceticus (this paper) are ubiquinol oxidases and can function in the absence of cytochrome $b_{556}$ or cytochrome $b_{554}$, respectively. Recently Murakami et al. (1985) provided evidence that cytochrome $b_{556}$ of $E$. coli is a product of the $s d h C$ gene (succinate dehydrogenase cluster) of $E$. coli, so that it may have a function in electron transfer from this dehydrogenase. Accordingly, investigations on the membrane-bound dehydrogenases of $A$. calcoaceticus may be rewarding in the assignment of a function to cytochrome $b_{554}$ of $A$. calcoaceticus.

We are grateful to Dr B. J. van Schie for providing part of the cell material and to P. P. Eijk, Mrs M. van der Meer-Van der Willik and L. van Sas for their technical assistance. This work was supported by a grant from the Dutch Ministry of Economic Affairs.

\section{References}

Ameyama, M., Nonobe, M., Shinagawa, E., Matsushita, K., TAKImoto, K. \& ADACHI, O. (1986). Purification and characterization of quinoprotein apo-D-glucose dehydrogenase from Escherichia coli. Agricultural and Biological Chemistry 50, 49-57.

ANRAKU, Y. \& GENNIS, R. B. (1987). The aerobic respiratory chain of Escherichia coli. Trends in Biochemical Sciences 12, 262-266.

AsPerger, O., Kleber, H.-P. \& Aurich, H. (1978). ZytochromZusammensetzung von Acinetobacter calcoacetius. Acta Biologica et Medica Germanica 37, 191-198.

AsPerger, O., Borneleit, P. \& Kleber, H.-P. (1981). Untersuchungen zum Elektronentransportsystem in Acinetobacter calcoaceticus. Abhandlungen der Akademie der Wissenschaften der DDR 3, 259-270.

Beardmore-Gray, M. \& ANTHONY, C. (1986). The oxidation of glucose by Acinetobacter calcoaceticus: interaction of the quinoprotein glucose dehydrogenase with the electron transport chain. Journal of General Microbiology 132, 1257-1268.

CARTER, K. \& GENNIS, R. B. (1985). Reconstitution of the ubiquinonedependent pyruvate oxidase system of Escherichia coli with the cytochrome $o$ terminal oxidase complex. Journal of Biological Chemistry 260, 10986-10990.

Chance, B. (1957). Techniques for the assay of the respiratory enzymes. Methods in Enzymology 4, 273-329.

Cleton-Jansen, A.-M., Goosen, N., Wenzel, T. J. \& Van de Putte, P. (1988). Cloning of the gene encoding quinoprotein glucose dehydrogenase from Acinetobacter calcoaceticus: evidence for the presence of a second enzyme. Journal of Bacteriology 170, 2121-2125.

Dokter, P., VAN Kleef, M. A. G., Frank, J., JZN \& Duine, J. A. (1985). Production of quinoprotein glucose dehydrogenase in the culture medium of Acinetobacter calcoaceticus. Enzyme and Microbial Technology 7, 613-617.

Dokter, P., Frank, J., Jzn \& Duine, J. A. (1986). Purification and characterization of quinoprotein glucose dehydrogenase in Acinetobacter calcoaceticus LMD 79.41. Biochemical Journal 239, 163-167.

DokTER, P., Van Wielink, J. E., Van Kleef, M. A. G. \& Duine, J. A. (1988). Cytochrome $b$-562 from Acinetobacter calcoaceticus LMD 79.41. Its characteristics and role as electron acceptor for quinoprotein glucose dehydrogenase. Biochemical Journal 254, 131-138.

ENSLEY, B. D. \& FINNERTY, W. R. (1980). Influences of growth substrates and oxygen on the electron transport chain system in Acinetobacter sp. HOI-N. Journal of Bacteriology 142, 859-868.

Ensley, B. D., Irwin, R. M., Carreira, L. A., Hoffman, P. S., MORGan, T. V. \& FinNerTy, W. R. (1981). Effects of growth substrate and respiratory chain composition on bioenergetics in Acinetobacter sp. strain HO1-N. Journal of Bacteriology 148, 508-513.

FuHRHOP, J. H. \& SMITH, K. M. (1975). Laboratory methods. In Porphyrins and Metalloporphyrins, pp. 757-869. Edited by K. M. Smith. Amsterdam: Elsevier.

GEIGER, O. \& GöRISCH, H. (1986). Crystalline quinoprotein glucose dehydrogenase from Acinetobacter calcoaceticus. Biochemistry 25, 6043-6048.

HaCKeTT, N. R. \& BRAGG, P. D. (1983). Membrane cytochromes of Escherichia coli grown aerobically and anaerobically with nitrate. Journal of Bacteriology 154, 708-718.

HADDOCK, B. A. \& JoNES, C. W. (1977). Bacterial respiration. Bacteriological Reviews 41, 47-99.

Hata, A., Kirino, Y., Matsuura, K., Hoh, S., Hiyama, T., Konishi, K., KITA, K. \& ANRAKU, Y. (1985). Assignment of ESR signals of Escherichia coli terminal oxidase complexes. Biochimica et Biophysica Acta 810, 62-72.

Hauge, J. G. (1960). Purification and properties of glucose dehydrogenase and cytochrome $b$ from Bacterium anitratum. Biochimica et Biophysica Acta 45, 250-262.

HAUGE, J. G. (1961). Mode of action of glucose dehydrogenase from Bacterium anitratum. Archives of Biochemistry and Biophysics 94, 308318.

Holloway, P. W. (1973). A simple procedure for removal of Triton X100 from protein samples. Analytical Biochemistry 53, 304-308.

KITA, K. \& ANRAKU, Y. (1981). Composition and sequence of $b$ cytochromes in the respiratory chain of aerobically grown Escherichia coli $\mathrm{K} \cdot 12$, in the early exponential phase. Biochemistry International 2, 105-112. 
Kita, K., Yamato, I. \& AnRaku, Y. (1978). Purifications and properties of cytochrome $b 556$ in the respiratory chain of aerobically grown Escherichia coli K12. Journal of Biological Chemistry 253, 8910-8915.

KITA, K., Konishi, K. \& ANRAKU, Y. (1984a). Terminal oxidases of Escherichia coli aerobic respiratory chain. I. Purification and properties of cytochrome $b 562-o$ complex from cells in the early exponential phase of aerobic growth. Journal of Biological Chemistry 259, 3368-3374.

Kita, K., Konishi, K. \& ANRaKU, Y. (1984b). Terminal oxidases of Escherichia coli aerobic respiratory chain. II. Purification and properties of cytochrome $b 558-d$ complex from cells grown with limited oxygen and evidence of branched electron-carrying systems. Journal of Biological Chemistry 259, 3375-3381.

Kita, K., Konishi, K. \& Anraku, Y. (1986). Purification and properties of two terminal oxidase complexes of Escherichia coli aerobic respiratory chain. Methods in Enzymology 126, 94-113.

Koland, J. G., Miller, M. J. \& Gennis, R. B. (1984). Reconstitution of the membrane-bound, ubiquinone-dependent pyruvate oxidase respiratory chain of Escherichia coli with the cytochrome $d$ terminal oxidase. Biochemistry 23, 445-453.

KRANZ, R. G. \& GENNIS, R. B. (1983). Immunological characterization of the cytochrome $o$ terminal oxidase from Escherichia coli. Journal of Biological Chemistry 258, 10614-10621.

Kranz, R. G. \& GENNIS, R. B. (1985). Immunological investigation of the distribution of cytochromes related to the two terminal oxidases of Escherichia coli in other Gram-negative bacteria. Journal of Bacteriology 161, 709-713.

Lorence, R. M., Green, G. N. \& Gennis, R. B. (1984). Potentiometric analysis of the cytochromes of an Escherichia coli mutant strain lacking the cytochrome $d$ terminal oxidase complex. Journal of Bacteriology 157, 115-121.

Matsushita, K., Patel, L., Gennis, R. B. \& Kaback, H. R. (1983). Reconstitution of active transport in proteoliposomes containing cytochrome $o$ oxidase and lac carrier protein purified from Escherichia coli. Proceedings of the National Academy of Sciences of the United States of America 80, 4889-4893.

Matsushita, K., Patel, L. \& Kaback, H. R. (1984). Cytochrome $o$ type oxidase from Escherichia coli. Characterization of the enzyme and mechanism of electrochemical proton gradient generation. Biochemistry 23, 4703-4714.

Matsushita, K., Shinagawa, E., Inoue, T., Adachi, O. \& Ameyama, M. (1986). Immunological evidence for two types of PQQ-dependent
D-glucose dehydrogenases in bacterial membranes and the location of the enzyme in Escherichia coli. FEMS Microbiology Letters 37, 141-144.

Matsushita, K., Nonobe, M., Shinagawa, E., Adachi, O. \& AMEYAMA, M. (1987). Reconstitution of pyrroloquinoline quinonedependent D-glucose oxidase respiratory chain of Escherichia coli with cytochrome $o$ oxidase. Journal of Bacteriology 169, 205-209.

Matsushita, K., Shinagawa, E., Adachi, O. \& Ameyama, M. (1988). Quinoprotein D-glucose dehydrogenase in Acinetobacter calcoaceticus LMD 79.41: the membrane-bound enzyme is distinct from the soluble enzyme. FEMS Microbiology Letters 55, 53-57.

Miller, M. J. \& GenNis, R. B. (1983). The purification and characterization of the cytochrome $d$ terminal oxidase complex of the Escherichia coli aerobic respiratory chain. Journal of Biological Chemistry 258, 9159-9165.

Murakami, H., Kita, K., Oya, H. \& Anraku, Y. (1985). The Escherichia coli cytochrome $b 556$ gene, $c y b A$, is assignable as $s d h C$ in the succinate dehydrogenase gene cluster. FEMS Microbiology Letters 30, 307-311.

Thomas, P. E., Ryan, D. \& Levin, W. (1976). An improved staining procedure for the detection of the peroxidase activity of cytochrome P-450 on sodium dodecyl sulfate polyacrylamide gels. Analytical Biochemistry 75, 168-176.

Van Schie, B. J., Van DiJken, J. P. \& Kuenen, J. G. (1984). Noncoordinate synthesis of glucose dehydrogenase and its prosthetic group PQQ in Acinetobacter and Pseudomonas species. FEMS Microbiology Letters 24, 133-138.

Van Wielink, J. E., OltManN, L. F., Leeuwerik, F. J., De Hollander, J. A. \& Stouthamer, A. H. (1982). A method for in situ characterization of $b$ - and $c$-type cytochromes in Escherichia coli and in Complex III from beef heart mitochondria by combined spectrum deconvolution and potentiometric analysis. Biochimica et Biophysica Acta 681, 177-190.

VAN Wielink, J. E., Reijnders, W. N. M., Oltmann, L. F. \& STOUTHAMER, A. H. (1983). Electron transport in aerobically grown Proteus mirabilis. Archives of Microbiology 136, 152-157.

White, C. C., Chain, R. K. \& Malkin, R. (1978). Duroquinol as an electron donor for chloroplast electron transfer reactions. Biochimica et Biophysica Acta 502, 127-137.

WIDDOWsON, D. \& ANTHONY, C. (1975). The microbial metabolism of $\mathrm{C}_{1}$ compounds. The electron-transport chain of Pseudomonas AM1. Biochemical Journal 152, 349-356. 